\title{
Therapy with Oral Clotrimazole Induces Inhibition of the Gardos Channel and Reduction of Erythrocyte Dehydration in Patients with Sickle Cell Disease
}

\author{
Carlo Brugnara, ${ }^{\star}$ Beatrice Gee, ${ }^{\star}$ Carrie C. Armsby, ${ }^{\star}$ Susan Kurth, ${ }^{\star}$ Masayuki Sakamoto, ${ }^{\star}$ Nader Rifai, ${ }^{\star}$ Seth L. Alper, ${ }^{\ddagger}$ \\ and Orah S. Platt* \\ *Departments of Laboratory Medicine, Pathology and Medicine, Children's Hospital and Harvard Medical School, Boston, \\ Massachusetts 02115, and ${ }^{\ddagger}$ Molecular Medicine Unit, Beth Israel Hospital, and Harvard Medical School, Boston, Massachusetts 02115
}

\begin{abstract}
Pathologic water loss from sickle erythrocytes concentrates the abnormal hemoglobin and promotes sickling. The $\mathrm{Ca}^{2+}$ activated $\mathrm{K}^{+}$channel (Gardos channel) contributes to this deleterious dehydration in vitro, and blockade of $\mathrm{K}^{+}$and water loss via this channel could be a potential therapy in vivo. We treated five subjects who have sickle cell anemia with oral clotrimazole, a specific Gardos channel inhibitor. Patients were started on a dose of $10 \mathrm{mg}$ clotrimazole $/ \mathrm{kg} / \mathrm{d}$ for one week. Protocol design allowed the daily dose to be escalated by $10 \mathrm{mg} / \mathrm{kg}$ each week until significant changes in erythrocyte density and $\mathrm{K}^{+}$transport were achieved. Blood was sampled three times a week for hematological and chemical assays, erythrocyte density, cation content, and $\mathrm{K}^{+}$transport. At dosages of $20 \mathrm{mg}$ clotrimazole/kg/d, all subjects showed Gardos channel inhibition, reduced erythrocyte dehydration, increased cell $\mathrm{K}^{+}$content, and somewhat increased hemoglobin levels. Adverse effects were limited to mild/moderate dysuria in all subjects, and a reversible increase in plasma alanine transaminase and aspartic transaminase levels in two subjects treated with $\mathbf{3 0}$ $\mathrm{mg}$ clotrimazole $/ \mathrm{kg} / \mathrm{d}$. This is the first in vivo evidence that the Gardos channel causes dehydration of sickle erythrocytes, and that its pharmacologic inhibition provides a realistic antisickling strategy. (J. Clin. Invest. 1996. 97:12271234.) Key words: K channel • imidazoles • erythrocyte • antisickling agents $\bullet$ clotrimazole
\end{abstract}

\section{Introduction}

The central objective in designing a therapy for sickle cell anemia $(\mathrm{SS})^{1}$ is to interfere with sickle hemoglobin $(\mathrm{Hb})$ polymerization-the reaction that causes the hallmark hemolysis and vascular obstruction (1). The reaction rate of this fundamental

Address correspondence to Carlo Brugnara, M.D., Clinical Laboratories, The Children's Hospital, 300 Longwood Avenue, Bader 760, Boston, MA 02115. Phone: 617-355-6347; FAX: 617-355-6081; E-mail: brugnara@a1.tch.harvard.edu

Received for publication 7 August 1995 and accepted in revised form 27 November 1995.

1. Abbreviations used in this paper: $\mathrm{CHCM}$, cell hemoglobin concentration mean; CLT, clotrimazole; $\mathrm{D}_{50}$, average erythrocyte density; $\mathrm{Hb}$, hemoglobin; LDH, lactic dehydrogenase; MCHC, mean corpuscular hemoglobin concentration; MCV, mean corpuscular volume; $\mathrm{R}_{60}$, median $60 \%$ density range; $\mathrm{SS}$, homozygous sickle cell anemia.

J. Clin. Invest.

(C) The American Society for Clinical Investigation, Inc.

0021-9738/96/03/1227/08 \$2.00

Volume 97, Number 5, March 1996, 1227-1234 process is highly dependent on the cellular concentration of $\mathrm{Hb} \mathrm{S}$ (2). Small decreases in $\mathrm{Hb} \mathrm{S}$ concentration can slow polymerization to the point where the transit time for erythrocytes to pass through capillaries becomes shorter than the delay time for $\mathrm{Hb} \mathrm{S}$ polymerization (2). One such successful therapeutic approach decreases the effective $\mathrm{Hb} \mathrm{S}$ concentration by diluting it with $\mathrm{Hb} \mathrm{F}$ (an $\mathrm{Hb}$ that does not participate in polymerization) using hydroxyurea to turn on silenced gamma globin genes (3-6).

Decreasing cellular $\mathrm{Hb} \mathrm{S}$ concentration by hypotonic swelling of erythrocytes has also been attempted, using water loading, vasopressin, and a low $\mathrm{Na}$ diet. This regimen indeed resulted in cell swelling, decreased cellular $\mathrm{Hb} \mathrm{S}$ concentration, and decreased sickling (7). Unfortunately the practical difficulty of chronically maintaining significant hyponatremia made these initial promising results unable to be reproduced in a subsequent study (8).

A more selective approach is to specifically inhibit the ion transport pathways that cause sickle erythrocytes to lose $\mathrm{K}^{+}$ and water. In vitro, $\mathrm{K}^{+}$and water loss from sickle cells can be attributed almost entirely to two specific transport pathways: the $\mathrm{K}-\mathrm{Cl}$ cotransport pathway, and the $\mathrm{Ca}^{2+}$-activated $\mathrm{K}^{+}$ channel (Gardos pathway). The $\mathrm{K}-\mathrm{Cl}$ cotransport is activated every time sickle cells are exposed to $\mathrm{pH}$ below 7.40, leading to cumulative net loss of $\mathrm{K}^{+}, \mathrm{Cl}$, and water (9-11). The $\mathrm{Ca}^{2+}$-activated $\mathrm{K}^{+}$channel, first described by Gardos (12), is activated by the increase in intracellular free $\mathrm{Ca}^{2+}$ concentration induced by sickling $(13,14)$. Approximately 100-150 Gardos channels are present in a normal erythrocyte (15). By using specific inhibitors, it should be possible to determine whether these pathways play a significant role in SS erythrocyte dehydration in vivo and thereby produce a significant reduction in cell $\mathrm{Hb} \mathrm{S}$ concentration. There are no specific inhibitors of the $\mathrm{K}-\mathrm{Cl}$ cotransport system which can be used clinically. Cetiedil, a very low affinity inhibitor of the Gardos channel, which also increases the $\mathrm{Na}^{+}$permeability (16), has shown some beneficial effects during acute sickle crises (17), but no further studies on this agent have been published in the last nine years.

In vitro work in normal (18) and sickle (19) erythrocytes has shown that clotrimazole (CLT) and other imidazole antimycotics are potent blockers of the erythrocyte Gardos channel, probably by blocking its external pore $(19,20)$. Studies in a transgenic mouse model (SAD mouse) for SS showed that oral CLT produced inhibition of the erythrocyte Gardos channel, increased erythrocyte $\mathrm{K}^{+}$content and decreased mean corpuscular hemoglobin concentration (MCHC) (21). Thus, in this mouse model for SS, the effects observed with oral CLT provide evidence for an in vivo role of the Gardos channel in cell dehydration.

Recently, we have described inhibition of the erythrocyte Gardos channel following oral CLT administration to normal human subjects (22). In these subjects and in control mice (21), CLT-induced inhibition of the Gardos channel was not associ- 
ated with changes in erythrocyte $\mathrm{K}^{+}$content, erythrocyte or reticulocyte $\mathrm{MCHC}$, and mean corpuscular volume (MCV), suggesting that under normal circumstances the Gardos channel does not play a role in determining the $\mathrm{K}^{+}$or water content of normal human or mouse erythrocytes. These findings were consistent with the predictions of a mathematical model on the regulation of water and ion content in normal human reticulocytes (23).

The use of oral CLT in individuals with SS should clarify the role of the Gardos channel in determining sickle cell dehydration in vivo. In this paper we demonstrate that oral administration of CLT to subjects with SS leads to inhibition of the erythrocyte Gardos channel, and to increased cell $\mathrm{K}^{+}$and water content, making it a potentially useful antisickling agent.

\section{Methods}

Patients. Individuals over 13 years of age with sickle cell anemia were eligible. Inclusion criteria included normal renal and liver function, no progressive or recent neurologic disease, and performance status of $70 \%$ or greater. Individuals who had been transfused within the preceding $90 \mathrm{~d}$, those maintained on chronic medications primarily metabolized by the cytochrome P-450 system, or those who were pregnant were excluded.

Approval for the study was obtained from the Institutional Review Board of Children's Hospital, Boston and by the Food and Drug Administration (Investigational New Drug Application no. 44,004). Written informed consent was obtained from each participant (and/ or guardian, if the subject was a minor) after the study had been completely explained by one of the investigators.

Study protocol. The diagnosis of sickle cell anemia was confirmed by cellulose acetate hemoglobin electrophoresis. The following studies were performed at the time of entry, three times weekly during the duration of the treatment, and weekly for one to two weeks thereafter: complete and differential blood counts, erythrocyte and reticulocyte indices, electrolytes, blood urea nitrogen (BUN), creatinine, ALT, AST, total and direct bilirubin, alkaline phosphatase, LDH, urinalyses, erythrocyte phthalate density profiles, and membrane transport studies (described in greater detail below). Female subjects had negative pregnancy tests before beginning the study. All patients were treated as outpatients. No patient was hospitalized during the study.

Subjects were given a starting dose of CLT $10 \mathrm{mg} / \mathrm{kg} / \mathrm{d}$ divided into two oral daily doses. Vaginal tablets containing $100 \mathrm{mg}$ of CLT (Gyne-Lotrimin ${ }^{\circledR}$, Schering-Plough Health Care Products, Liberty Corner, NJ) were used for this study. After each week of therapy, subjects were evaluated as to whether they had attained a threshold cellular response to CLT, defined as greater than a $10 \%$ reduction in dense cells $(\mathrm{d}>1.120$ measured with the phthalate density profile) or greater than $50 \%$ inhibition of the erythrocyte Gardos channel. In the absence of an adequate response, the CLT dose was increased by 10 $\mathrm{mg} / \mathrm{kg} / \mathrm{d}$ for the following week. The approved protocol allowed for weekly dose escalations of $10 \mathrm{mg} / \mathrm{kg} / \mathrm{d}$, up to a maximum of $60 \mathrm{mg} / \mathrm{kg} / \mathrm{d}$. If the threshold cellular response had been achieved, the subjects continued CLT at the same dose for an additional week and the medication was then stopped. CLT was to be discontinued if the subjects experienced significant clinical or laboratory side effects.

Measurement of ${ }^{86} \mathrm{Rb}$ influx in whole blood. Three 1-ml aliquots of blood collected in Na-heparin were incubated for $60 \mathrm{~min}$ at room temperature in 1.5-ml Eppendorf tubes in the presence of A23187 (80 $\mu \mathrm{mol} / \mathrm{l}$ blood) and Tris-3-[ $N$-morpholino] propanesulfonic acid (Mops; $20 \mathrm{mM}$ in plasma). Tubes were wrapped in aluminum foil, to prevent inactivation of A23187 by light and gently rotated (15 rotations/min). At the end of the incubation, $100 \mu l$ of blood was spun through $0.5 \mathrm{ml} n$-butylphthalate and an aliquot of the resulting plasma was taken for measurement of $\mathrm{K}^{+}$concentration by atomic absorption. The remaining $0.9 \mathrm{ml}$ of blood was centrifuged at 6,000 rpm for $10 \mathrm{~s}$ in a microfuge. ${ }^{86} \mathrm{Rb}(2 \mu \mathrm{Ci} / \mathrm{ml}$ blood $)$ was added to the supernatant, and the cell pellets were resuspended to initiate the influx assay. At specified time intervals ( 1 and $3 \mathrm{~min}$ ), triplicate $0.1-\mathrm{ml}$ aliquots were taken and spun through $0.8 \mathrm{ml}$ of saline medium containing 15 mM EGTA, pH 7.4, layered over a 0.4-ml cushion of $n$-butylphthalate. After aspiration of the supernatant and upper layer of oil, the remaining tube contents were frozen in acetone/dry ice, the tube tip containing the cell pellet was cut off, and the erythrocyte-associated radioactivity was counted in a Micromedics $2000 \mathrm{HE}$ gamma counter. At the 3-min time point, the supernatant was removed for determination of ${ }^{86} \mathrm{Rb}$ specific activity. Preliminary experiments indicated no significant changes in the external $\mathrm{K}$ concentration between 0 and 3 min. ${ }^{86} \mathrm{Rb}$ influx was calculated as detailed in references 15 and 22.

Hematology and chemistry assays. Erythrocyte cation content and phthalate density profiles were determined as described previously (4). Three parameters were evaluated with the phthalate density profile: (a) $\mathrm{D}_{50}$, or median density, is the density value at which $50 \%$ of the cells are lighter and $50 \%$ of the cells are denser. This value is often increased in sickle cell disease. The error of the assay, determined with repeated measurements in a normal subject, is \pm 0.001 density units. (b) $\mathbf{R}_{60}$, or median $60 \%$ density range, obtained after subtracting the lightest $20 \%$ and the densest $20 \%$ cell fractions. This value is increased in sickle cells, reflecting the heterogeneity in cell densities
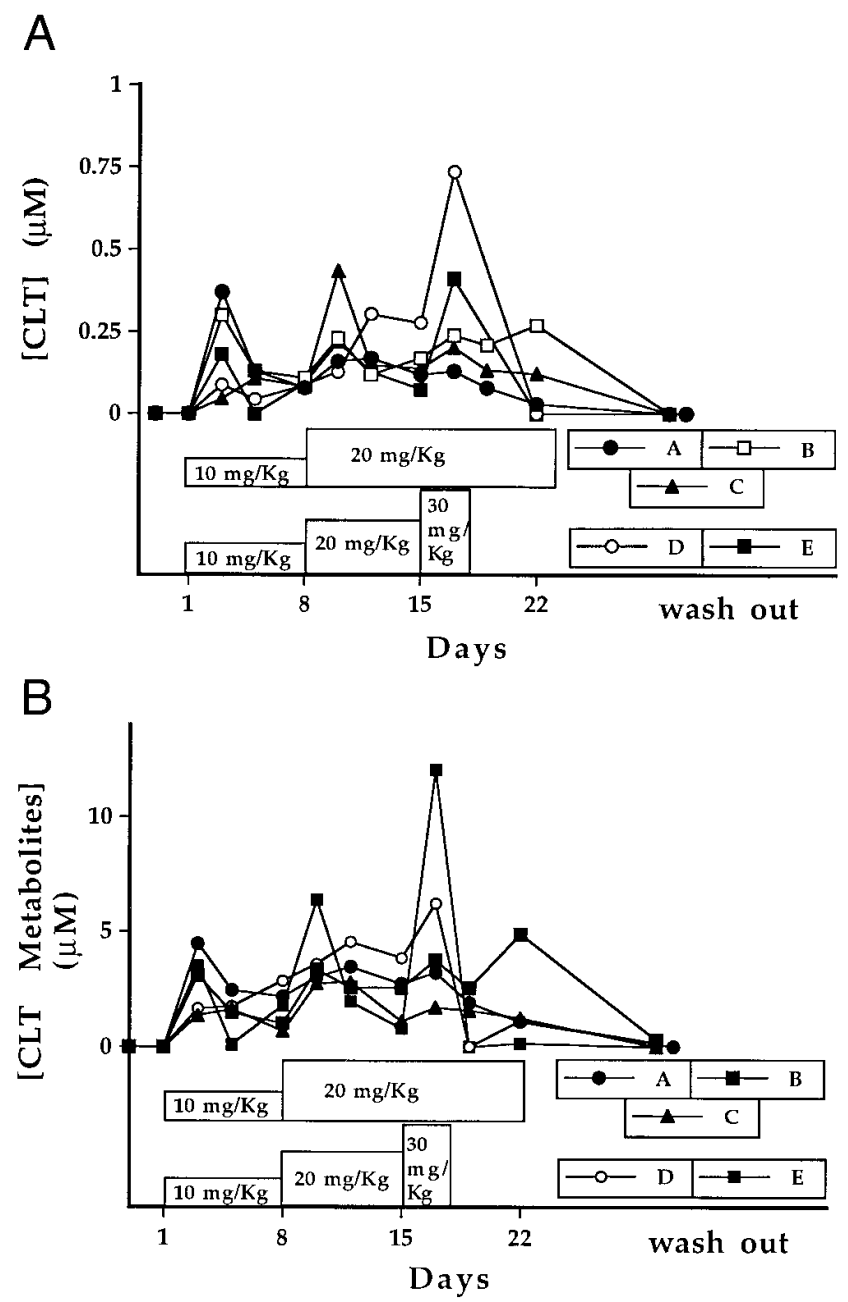

Figure 1. (A) Plasma levels of CLT and $(B)$ summed plasma levels of two major CLT metabolites (Met A and B) $(22,24)$ following oral administration of CLT in five subjects with sickle cell disease. 
Table I. Laboratory Values at Baseline During and after Treatment with Oral Clotrimazole

\begin{tabular}{|c|c|c|c|c|c|c|c|c|c|c|c|}
\hline \multirow[b]{2}{*}{ Patient Time/CLT } & \multicolumn{5}{|c|}{ Hematological data } & \multicolumn{5}{|c|}{ Plasma chemistries } & \multirow{2}{*}{$\frac{\text { Urine }}{\text { U WBC }}$} \\
\hline & $\mathrm{Hb}$ & $\mathrm{MCV}$ & $\mathrm{MCHC}$ & Retics. & WBC & PLT & ALT & LDH & Bili T & Bili Ind & \\
\hline days $(\mathrm{mg} / \mathrm{Kg})$ & $g / l$ & $f l$ & $g / d l$ & $10^{6} / \mathrm{mm}^{3}$ & $10^{3} / \mathrm{mm}^{3}$ & $10^{3} / \mathrm{mm}^{3}$ & $U / l$ & $U / l$ & $m g / d l$ & $m g / d l$ & \\
\hline A Baseline & 6.7 & 86 & 34.2 & 0.26 & 11.3 & 310 & 8 & 563 & 5.5 & 5.2 & - \\
\hline $5(10)$ & 6.8 & 86 & 33.7 & 0.21 & 10.8 & 307 & 6 & 531 & 3.3 & 3 & 4 \\
\hline $12(20)$ & 7.3 & 85 & 33.2 & 0.26 & 10.3 & 363 & 8 & 439 & 1.9 & 1.5 & 1 \\
\hline $19(20)$ & 7.2 & 85 & 32.7 & 0.26 & 10.9 & 354 & 9 & 425 & 1.7 & 1.3 & $2-4$ \\
\hline Wash out, $10 \mathrm{~d}$ & 6.7 & 82 & 34.3 & 0.23 & 11.2 & 281 & 11 & 521 & 3.1 & 2.7 & - \\
\hline B Baseline & 7 & 88 & 34.5 & 0.29 & 9.3 & 279 & 13 & 631 & 6.8 & 6.3 & - \\
\hline $5(10)$ & 6.7 & 87 & 33.3 & 0.22 & 9.4 & 264 & 14 & 560 & 3.4 & 3 & 10 \\
\hline $12(20)$ & 7.4 & 85 & 33.6 & 0.25 & 8.7 & 366 & 12 & 507 & 2.1 & 1.7 & 1 \\
\hline $19(20)$ & 7.4 & 85 & 33.1 & 0.27 & 10 & 333 & 10 & 435 & 2.2 & 1.7 & 1 \\
\hline Wash out, $10 \mathrm{~d}$ & 6.6 & 85 & 33.3 & 0.24 & 10.9 & 279 & 10 & 582 & 3.1 & 2.7 & $0-1$ \\
\hline C Baseline & 7.8 & 89 & 32.1 & 0.29 & 12.3 & 371 & 12 & 617 & 7.8 & 7.5 & - \\
\hline $5(10)$ & 8.1 & 92 & 32.3 & 0.42 & 11.2 & 401 & 28 & 645 & 4 & 3.8 & $2-4$ \\
\hline $12(20)$ & 8.5 & 92 & 32.6 & 0.27 & 8.7 & 376 & 15 & 497 & 2.2 & 1.8 & - \\
\hline $19(20)$ & 8.5 & 90 & 33.1 & 0.21 & 9.3 & 364 & 12 & 499 & 1.7 & 1.4 & - \\
\hline Wash out, $16 \mathrm{~d}$ & 8.5 & 96 & 32.9 & 0.30 & 11.9 & 354 & 34 & 434 & 2.5 & 2.2 & - \\
\hline D Baseline & 6.9 & 96 & 31.6 & 0.17 & 8.0 & 246 & 18 & 476 & 3.5 & 3.1 & - \\
\hline $5(10)$ & 6.7 & 95 & 31.9 & 0.35 & 7.1 & 362 & 15 & 451 & 2.2 & 1.7 & - \\
\hline $12(20)$ & 7.1 & 96 & 31.4 & 0.30 & 6.9 & 360 & 15 & 410 & 1.7 & 1.3 & - \\
\hline $17(30)$ & 7.8 & 93 & 33.6 & 0.22 & 10.7 & 357 & 55 & 505 & 2.2 & 1.5 & - \\
\hline Wash out, $16 \mathrm{~d}$ & 5.8 & 87 & 35.1 & - & 10.1 & 246 & 29 & 540 & 3.1 & 2.5 & - \\
\hline E Baseline & 9.5 & 68 & 31.3 & 0.31 & 13.5 & 360 & 34 & 421 & 2.1 & 1.7 & - \\
\hline $5(10)$ & 9 & 67 & 32.3 & 0.23 & 11.5 & 340 & 29 & 397 & 1.9 & 1.7 & - \\
\hline $12(20)$ & 9.6 & 68 & 31.7 & 0.29 & 8.2 & 368 & 24 & 422 & 1 & 0.8 & - \\
\hline $17(30)$ & 9.4 & 65 & 33 & 0.11 & 7.2 & 267 & 91 & 416 & 1.2 & 1.0 & - \\
\hline Wash out, $12 \mathrm{~d}$ & 8.3 & 68 & 31 & 0.17 & 10.1 & 499 & 32 & 305 & 1.0 & 0.8 & - \\
\hline
\end{tabular}

Patients with A, B, and C were treated with CLT for one week at $10 \mathrm{mg} / \mathrm{kg} / \mathrm{d}$ and for two subsequent weeks at $20 \mathrm{mg} / \mathrm{kg} / \mathrm{d}$. Patients D and E were treated for one week at $10 \mathrm{mg} / \mathrm{kg} / \mathrm{d}$, one subsequent week at $20 \mathrm{mg} / \mathrm{kg} / \mathrm{d}$, and 3 final days at $30 \mathrm{mg} / \mathrm{kg} / \mathrm{d}$.

typical of this disease. The error of the assay, determined with repeated measurements in a normal subject, is \pm 0.001 density units. (c) Percent dense cells, expressed as the percentage of cells with density higher than 1.120. The presence of dense cells is a defining characteristic of sickle cell disease and no dense cells are present in normal blood.

CLT levels in plasma and whole blood were determined by reverse phase HPLC (24). No attempts were made to standardize the amount of time that transpired between the oral administration of CLT and the subsequent blood sampling for measurements of plasma CLT levels.

Complete blood count (CBC), erythrocyte indices, percent reticulocytes and reticulocyte indices were measured with the $\mathrm{H}^{*} 3$ Bayer Hematology analyzer. This instrument measures percent reticulocytes based on the absorbance of the dye Oxazine 750 and quantifies reticulocyte cellular indices such as cell volume (MCVr), cell $\mathrm{Hb}$ concentration (CHCMr) and cell $\mathrm{Hb}$ content (CHr) (25).

Plasma levels of BUN, creatinine, ALT, AST, ALP, and other blood chemistries were measured using standard assays on a Boehringer/Hitachi 911 chemistry analyzer (Boehringer Mannheim Corp., Indianapolis, IN; Hitachi Sci. Instrs., Mountain View, CA).

\section{Results}

Plasma levels of clotrimazole and its metabolites. After the first week of oral CLT treatment at dosages of $10 \mathrm{mg} \mathrm{CLT} / \mathrm{kg} / \mathrm{d}$, the dosages of all five subjects were escalated to $20 \mathrm{mg} \mathrm{CLT} / \mathrm{kg} / \mathrm{d}$.
Three subjects (A, B, C) were maintained for one additional week at this dosage, while in two subjects $(\mathrm{D}, \mathrm{E})$ CLT dosage was escalated to $30 \mathrm{mg} / \mathrm{kg}$. As shown in Fig. 1, oral administration of CLT in subjects A, B, and C was associated with random plasma levels of CLT varying between 0.03 and $0.44 \mu \mathrm{M}$. These values are in accordance with published data on blood levels of CLT following oral administration in normal controls or patients with systemic mycoses (26-29). In two subjects (D and E) higher levels of plasma CLT were achieved at dosages of $30 \mathrm{mg} \mathrm{CLT} / \mathrm{kg} / \mathrm{d}$ (0.74 and $0.41 \mu \mathrm{M}$, respectively; Fig. 1). These levels were associated with nausea, vomiting, and increased plasma alanine transaminase (ALT) and aspartic transaminase (AST) levels (see below and Table I).

Two additional major peaks were detected in the HPLC extract, consistent with the presence of CLT metabolites (22, 30). Micromolar levels of CLT metabolites were present in plasma following CLT administration in the five subjects (maximum values ranging from $2.8 \mu \mathrm{M}$ for subject $\mathrm{C}$ to 12.5 $\mu \mathrm{M}$ for subject E; Fig. $1 B$ ). Given the known sensitivity of the Gardos channel to CLT and its metabolite(s), we predicted that these levels should result in significant inhibition of $\mathrm{K}^{+}$, $\mathrm{Cl}^{-}$, and water transport.

Effects on erythrocyte Gardos channel, $K^{+}$content and density. Fig. $2 A$ and Table II present data on the changes in 

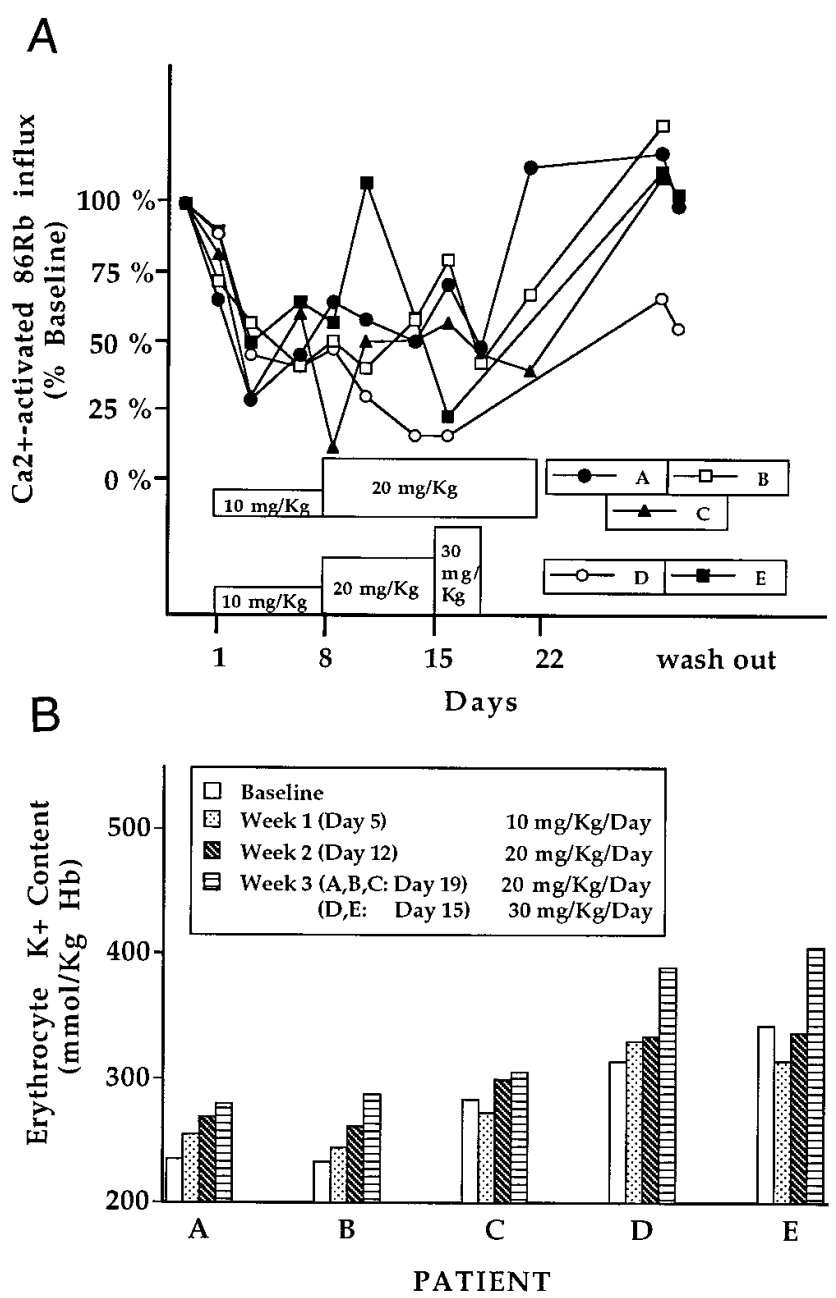

Figure 2. (A) Inhibition of $\mathrm{Ca}^{2+}$-activated ${ }^{86} \mathrm{Rb}$ influx by oral administration of CLT as a function of time following oral administration of CLT in five subjects with sickle cell disease. $(B)$ Changes in erythrocyte $\mathrm{K}^{+}$content during CLT administration in five subjects with sickle cell disease.

erythrocyte Gardos channel activity in the five subjects during CLT administration. This channel is silent under normal conditions, and is studied experimentally by measuring the transport of $\mathrm{K}^{+}$in the presence of external $\mathrm{Ca}^{2+}$ and a $\mathrm{Ca}^{2+}$ ionophore (A23187). The ionophore increases the $\mathrm{Ca}^{2+}$ content of the erythrocytes thereby maximally activating the channel (22, 31 ). Inhibition levels varied from 0 to $89 \%$ in the five subjects during the $3 \mathrm{wk}$ of CLT administration (maximum inhibition: $69 \%$ in $\mathrm{A}, 65 \%$ in $\mathrm{B}, 89 \%$ in $\mathrm{C}, 80 \%$ in $\mathrm{D}$, and $80 \%$ in E). Although there are no data available on the role of the Gardos channel in promoting dehydration in vivo, the levels of inhibition observed in these five patients theoretically should be associated with an increased cell $\mathrm{K}^{+}$content and a reduced percentage of dense cells, if the Gardos channel does indeed promote dehydration of sickle erythrocytes.

Fig. $2 B$ and Table II present data on the cell $\mathrm{K}^{+}$content and the percentage of dense cells in the five subjects treated with oral CLT. Fig. 3 presents the changes in the phthalate density profile for the five subjects at different CLT dosages. In all subjects, the cell $\mathrm{K}^{+}$content increased during CLT administration (Fig. $2 \mathrm{~B}$ ), and returned toward baseline after
CLT was discontinued (data not shown). In two subjects (A and B), CLT administration was associated with a significant decrease of the cell $\mathrm{Na}^{+}$content, which was markedly elevated at baseline, decreased significantly during CLT therapy (Table II), and returned toward baseline when CLT was discontinued (not shown). This decrease in cell $\mathrm{Na}^{+}$partially offset the increase in cell $\mathrm{K}^{+}$, so that the increase in total cation content was less than the observed increase in cell $\mathrm{K}^{+}$(Table II).

The phthalate density method (32) provides valuable information on, and quantification of, the presence of dense cells. As shown in Fig. 3 and Table II, there was a significant reduction in the median erythrocyte density $\left(D_{50}\right)$. Four of the five subjects, (A, B, C, and D) had a significant reduction in the percentage of dense cells and the median $60 \%$ density range $\left(R_{60}\right)$. The percentage of dense cells and $R_{60}$ are typically increased in sickle cell disease, reflecting erythrocyte dehydration and cell heterogeneity, respectively. The subject (E) who showed no changes in $\mathrm{D}_{50}, \mathrm{R}_{60}$, or the percentage of cells denser than 1.120 had no dense cells at the beginning of the trial, most likely as a consequence of concomitant $\alpha$ thalassemia (MCV $68 \mathrm{fL}$, normal iron indices).

In two subjects (A and B) there was a significant increase in $\mathrm{K}-\mathrm{Cl}$ cotransport activity during CLT therapy. In the five patients combined, no significant changes in $\mathrm{K}-\mathrm{Cl}$ cotransport were observed (Table II).

Absolute reticulocyte counts and reticulocyte cellular indices [reticulocyte mean corpuscular volume (MCVr), reticulocyte mean cell hemoglobin concentration ( $\mathrm{CHCMr})$, and reticulocyte cell hemoglobin content ( $\mathrm{CHr}$; reference 25)] were measured in three of the five subjects. No significant changes were observed during CLT administration (data not shown). In the five subjects, red cell $\mathrm{MCHC}$ did not change significantly with CLT therapy. This is not surprising, since MCHC is just the mean for a broad distribution of cell hemoglobin concentration values, and is not as sensitive as the phthalate technique to density changes occurring in a subpopulation of red cells. Significant changes were observed in the percent of cells with hemoglobin concentration $>38 \mathrm{~g} / \mathrm{dl}$, which is an estimate of dense cells obtained with the $\mathrm{H}^{*} 3$ Bayer analyzer (Table II).

Hematological/biochemical changes and side effects. CLT administration was associated with a significant increase in blood $\mathrm{Hb}$ levels (1-tail or 2-tail paired $t$ test: $P<0.05$ at day 12 , average increase $0.4 \mathrm{~g} / \mathrm{dl} ; P<0.05$ at day 19 , average increase $0.5 \mathrm{~g} / \mathrm{dl}$, subjects A, B, and C; $P<0.05$ at day 17/19, all 5 subjects, average increase $0.5 \mathrm{~g} / \mathrm{dl}$; see Table I). Since we did not measure red cell mass, or plasma volume, the increased $\mathrm{Hb}$ values have to be interpreted with some caution. Moreover, this increase in blood $\mathrm{Hb}$ levels was not associated with a statistically significant reduction in other hemolysis indices, such as plasma lactic dehydrogenase (LDH; Table I) or free hemoglobin (data not shown), even though plasma LDH values decreased during CLT administration in subjects A, B, and C. There were also no significant changes in the absolute number of reticulocytes during CLT treatment.

In all five subjects, CLT treatment was associated with marked reduction in indirect bilirubin levels (Table I). Three subjects (A, B, and $\mathrm{C}$ ) presented with elevated baseline indirect bilirubin levels $(5.2,6.3$, and $7.5 \mathrm{mg} / \mathrm{dl}$, respectively) that decreased during CLT treatment to levels of 1.7, 2.2, and 1.7 $\mathrm{mg} / \mathrm{dl}$, respectively.

Side effects of CLT were minimal at doses of $10-20 \mathrm{mg} / \mathrm{kg}$. All subjects experienced mild dysuria, and there was an occa- 


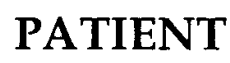

WEEK 1:

10mg CLT

/Kg/Day

A

B

C

D

E
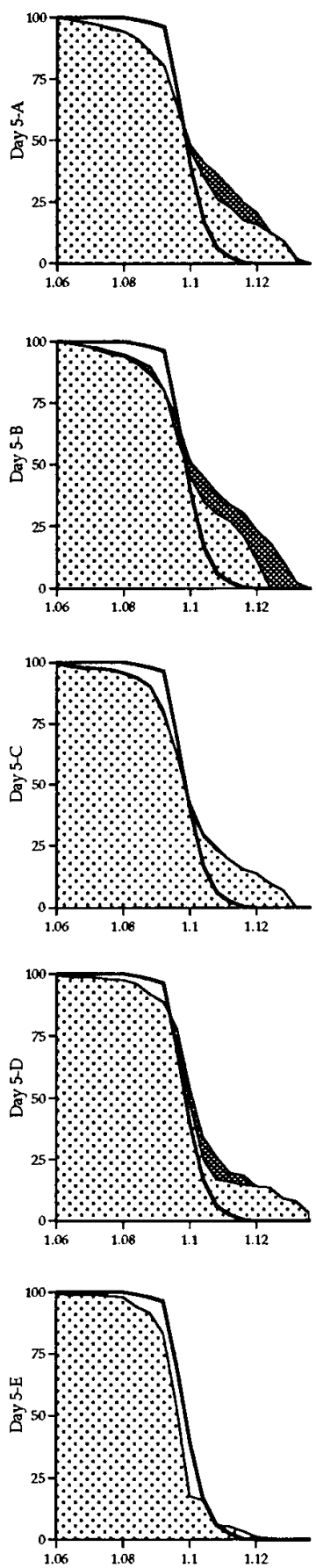

WEEK 2: 20mg CLT

/Kg/Day
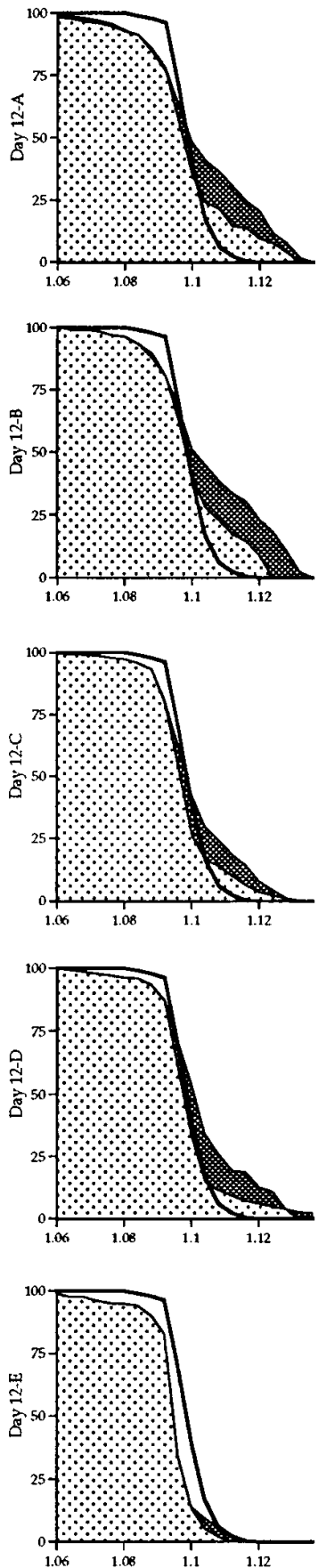

WEEK 3:

A,B,C: 20mg CLT/Kg/Day

D,E: 30mg CLT/Kg/Day
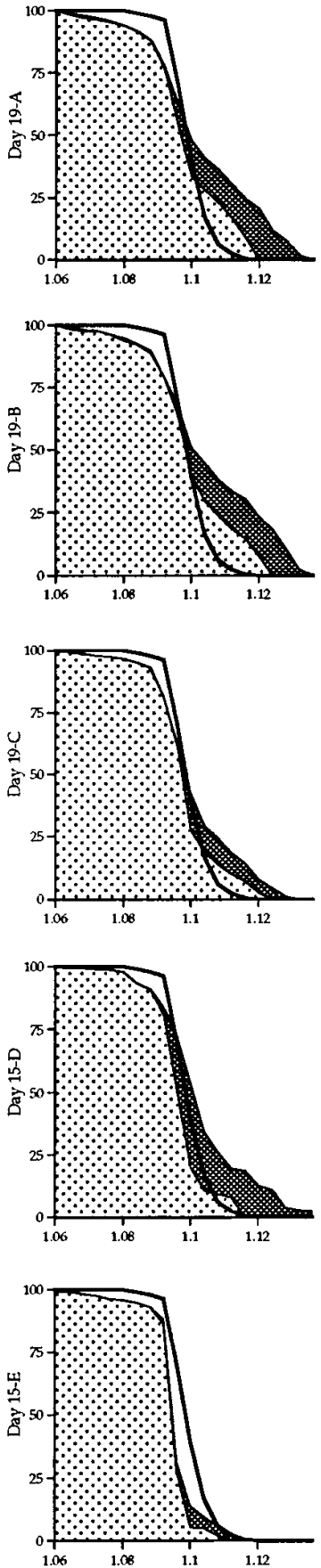

\section{Specific Density}

Figure 3. Phthalate density profiles before and during oral CLT administration in five subjects with sickle cell disease. The percentage of denser cells (y axis) is plotted against the density of the phthalate esters used. In each graph, the density profile of normal AA control erythrocytes is also presented, to show the increase in the percentage of dense cells characteristic of sickle cell disease. The shaded grey area corresponds to the decrease in dense cells compared with baseline measurement for each subject. 


\begin{tabular}{|c|c|c|c|c|c|c|c|c|c|}
\hline Patient Time CLT dose & Cell Na & Cell K & Cell $\mathrm{Na}+\mathrm{K}$ & $\mathrm{D}_{50}$ & $\mathrm{R}_{60}$ & Dense cells & $\mathrm{CHCM}>38 \mathrm{~g} / \mathrm{dL}$ & $\begin{array}{l}\text { Gardos } \\
\text { inhibition }\end{array}$ & $\mathrm{K}-\mathrm{ClCOT}$ \\
\hline days $(\mathrm{mg} / \mathrm{Kg})$ & $\begin{array}{c}\mathrm{mmol} / \mathrm{kg} \\
\text { hemoglobin }\end{array}$ & & & & & $\%$ & $\%$ & $\%$ & $\begin{array}{l}m m o l / l \\
\text { cell } \times h\end{array}$ \\
\hline A Baseline & 68.3 & 235.1 & 303.4 & 1.099 & 0.029 & 31.7 & 23.3 & 0 & 26.0 \\
\hline $5(10)$ & 54.6 & 254.9 & 309.5 & 1.099 & 0.022 & 22.7 & 18.7 & 73 & 28.2 \\
\hline $12(20)$ & 47.8 & 269.3 & 317.1 & 1.097 & 0.018 & 14.3 & 14.5 & 45 & 31.6 \\
\hline $19(20)$ & 45 & 280.0 & 325.0 & 1.096 & 0.019 & 16.7 & 19.9 & 55 & 30.5 \\
\hline B Baseline & 72.6 & 232.9 & 305.5 & 1.100 & 0.031 & 33.3 & 24.3 & 0 & 25.8 \\
\hline $5(10)$ & 55 & 244.3 & 299.3 & 1.099 & 0.024 & 27.1 & 18.9 & 51 & 29.6 \\
\hline $12(20)$ & 47.1 & 261.4 & 308.5 & 1.098 & 0.017 & 17.3 & 14.9 & 65 & 32.2 \\
\hline $19(20)$ & 47.7 & 287.2 & 334.9 & 1.098 & 0.018 & 18.5 & 20.4 & 63 & 30.5 \\
\hline C Baseline & 45.4 & 283.1 & 328.5 & 1.099 & 0.020 & 20.5 & 18.9 & 0 & 32.8 \\
\hline $5(10)$ & 53.2 & 272.6 & 325.8 & 1.098 & 0.020 & 19.1 & 16.3 & 71 & 29.9 \\
\hline $12(20)$ & 43.8 & 299.4 & 343.2 & 1.097 & 0.011 & 10.0 & 11.9 & 52 & 33.4 \\
\hline $19(20)$ & 42.5 & 305.2 & 347.7 & 1.097 & 0.011 & 10.0 & 7.7 & 56 & 25.9 \\
\hline D Baseline & 36.6 & 314 & 350.6 & 1.101 & 0.024 & 16.2 & 11.4 & 0 & 21.1 \\
\hline $5(10)$ & 32.8 & 330.1 & 362.9 & 1.100 & 0.012 & 13.9 & 10.7 & 44 & 22.1 \\
\hline $12(20)$ & 28.6 & 334 & 362.6 & 1.098 & 0.010 & 6.0 & 6.4 & 63 & 23.4 \\
\hline $17(30)$ & 25.8 & 388.9 & 414.7 & 1.096 & 0.008 & 0 & 6.3 & 80 & 24.1 \\
\hline E Baseline & 35.7 & 342.7 & 378.4 & 1.095 & 0.010 & 0 & ND & 0 & 17.5 \\
\hline $5(10)$ & 30.3 & 314.5 & 344.8 & 1.096 & 0.011 & 0 & ND & 53 & 20.9 \\
\hline $12(20)$ & 33.2 & 337.3 & 370.5 & 1.095 & 0.007 & 0 & ND & 0 & 21.9 \\
\hline $17(30)$ & 33.2 & 404.9 & 438.1 & 1.095 & 0.007 & 0 & ND & 44 & 13.8 \\
\hline $\begin{array}{l}\text { CLT-induced } \\
\text { change }( \pm \mathrm{SD})\end{array}$ & $-8.35(10.9)$ & $24.1(27.6)$ & $13.7(24.7)$ & $-0.002(0.002)$ & $-0.008(0.005)$ & $-8.6(6.5)$ & $-5.6(3.0)$ & $58.2(11.3)$ & $-1.9(3.7)$ \\
\hline$P<$ & NS & 0.005 & 0.05 & 0.005 & 0.0001 & 0.0002 & 0.0001 & 0.0001 & NS \\
\hline
\end{tabular}

Patients A, B, and C were treated with CLT for one week at $10 \mathrm{mg} / \mathrm{kg} / \mathrm{d}$ and for two subsequent weeks at $20 \mathrm{mg} / \mathrm{kg} / \mathrm{d}$. Patients D and E were treated for one week at $10 \mathrm{mg} / \mathrm{kg} / \mathrm{d}$, one subsequent week at $20 \mathrm{mg} / \mathrm{kg} / \mathrm{d}$, and 3 final days at $30 \mathrm{mg} / \mathrm{kg} / \mathrm{d}$. Baseline values are the mean of two separate pre-

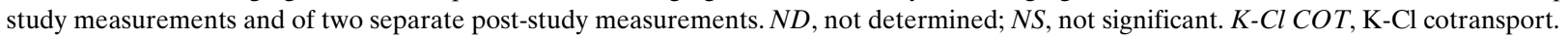

sional episode of nausea or dizziness. Dysuria disappeared with discontinuation of CLT. Urinalysis showed a maximum of 10 white blood cells (WBC)/high power field in one of the five subjects in the absence of urinary tract infection. Urinalysis normalized after cessation of CLT. This side effect had been reported in the past and it is most likely due to the urinary elimination of CLT metabolites (29). Subjects A, B, and C each reported dizziness on a single occasion.

Subjects D and E experienced nausea and vomiting $\sim 24 \mathrm{~h}$ after CLT was increased to $30 \mathrm{mg} / \mathrm{kg}$. CLT was discontinued after this occurred and there was no further nausea or vomiting within $24 \mathrm{~h}$ of stopping CLT. Both subjects had marked elevation of liver enzymes at the time of the nausea and vomiting (subject D, peak plasma levels: AST 158, ALT 78; subject E, peak plasma levels: AST 122, ALT 91; also see Table I). Bilirubin, $\mathrm{LDH}$, and alkaline phosphatase were not elevated during this period. Liver enzymes returned to baseline following CLT withdrawal (subject D, 25-d follow-up, and subject E, 12-d follow-up).

\section{Discussion}

We have shown that oral administration of clotrimazole leads to marked inhibition of the erythrocyte Gardos channel in five subjects with sickle cell disease. In four subjects who had a significant percentage of dense, dehydrated sickle cells before treatment, CLT caused a marked reduction in the number of these pathologic cells, and overall erythrocyte density (Table I and Fig. 3). This reduction in cell density was associated with increased cell $\mathrm{K}^{+}$content, indicating for the first time that the erythrocyte Gardos channel plays a significant role in the formation of dense, dehydrated sickle erythrocytes in vivo. One of the subjects (E) lacked dense cells, probably as a result of the concomitant presence of $\alpha$ thalassemia. In this subject, inhibition of the Gardos channel was associated with no significant changes in cell density.

Interestingly, no significant changes were observed in the cell volume or hemoglobin concentration of reticulocytes (measured in three subjects), suggesting that the Gardos channel may play a greater role in the dehydration of mature sickle cells than reticulocytes. It remains to be established in vivo that dehydration of sickle reticulocytes can be attributed to $\mathrm{K}-\mathrm{Cl}$ cotransport, as suggested by in vitro data $(33,34)$.

These effects on erythrocyte density and $\mathrm{K}^{+}$transport were obtained at dosages of $20 \mathrm{mg} \mathrm{CLT} / \mathrm{kg} / \mathrm{d}$, which are substantially lower than those previously used to treat systemic mycoses (100-160 mg/kg/d) (29). At the relatively low dosages of $20 \mathrm{mg} / \mathrm{kg} / \mathrm{d}$, CLT was well tolerated, with the major side effect 
being mild/moderate dysuria, sometimes with pyuria, likely due to urinary excretion of CLT metabolites (29). The two subjects treated with higher dosages $(30 \mathrm{mg} / \mathrm{kg} / \mathrm{d})$ experienced significant nausea and vomiting, with increased ALT and AST that returned to baseline after CLT was discontinued. Such toxicity was unexpected at $30 \mathrm{mg} \mathrm{CLT} / \mathrm{kg} / \mathrm{d}$, since it had been described mostly at higher dosages, and may reflect an increased sensitivity of subjects with sickle cell disease.

This short-term study was designed to evaluate the cellular effects and possible toxicity of oral CLT in subjects with sickle cell disease. We were surprised by the increase in $\mathrm{Hb}$ levels and decreased indirect plasma bilirubin levels observed after only two weeks of CLT administration (Table I). Although these results indicate that CLT may reduce hemolysis, we did not observe significant change in plasma LDH or free hemoglobin levels, and the dramatic decrease in plasma indirect bilirubin level could be the result of hepatic microsomal induction, which has been described for CLT and the cytochrome P450 system (29).

The inhibition/induction of cytochrome P450-dependent enzymes is not a feature of the CLT metabolites, probably because of the enzymatic removal of the imidazole ring (30). These data, together with our finding that CLT metabolites are active as inhibitors of the Gardos channel (22), open the possibility for rational design of a second generation of $\mathrm{Ca}^{2+}$ activated $\mathrm{K}^{+}$channel inhibitors, with a different toxicity profile from that of the "first generation" imidazole derivatives.

Other biological effects of CLT will need to be evaluated in long-term clinical trials. These effect include inhibition of $\mathrm{Ca}^{2+}$ entry via the dihydropyridine-sensitive $\mathrm{Ca}^{2+}$ channels of the plasma membrane $(35,36)$, inhibition of cell proliferation (37), and blockade of release of von Willebrand factor from cultured endothelial cells $(38,39)$. Studies in a mouse model for $\beta$ thalassemia have indicated that combination of CLT with either recombinant human erythropoietin (r-HuEPO) or hydroxyurea induces a greater increase in $\mathrm{Hb}$ levels compared to therapy with r-HuEPO or hydroxyurea alone (40). While the bases for this potentiation induced by CLT are not yet clarified, its applicability to human SS needs to be evaluated.

This study indicates that it is possible to prevent dehydration of sickle erythrocytes in vivo by specifically blocking one of the pathways involved in the loss of cell $\mathrm{K}^{+}$. The effects of CLT are more evident in patients with a significant number of dense cells as baseline. It remains to be determined whether it will benefit patients with few or no dense cells, such as $S / \beta$ thal or SS/ $\alpha$ thal. Future studies will also address the issues of longterm treatment and combination therapy with other antisickling agents.

\section{Acknowledgments}

This work is dedicated to Dr. George Gardos and in memoriam to Dr. John C. Parker for their contributions to transport physiology.

We would like to thank Dr. K. Bridges and Ms. C. Winograd (Brigham and Women's Hospital), Dr. L. McMahon and Ms. G. Weinberg (Boston City Hospital), and Dr. F. Tauber (Center for the Philosophy and History of Science, Boston) for referring patients for this study. We wish to thank Dr. M. Sorette of Bayer Diagnostics (Tarrytown, NY) for the analysis of $\mathrm{H}^{*} 3$ Bayer data.

This work was supported by a grant from the Heart, Lung and Blood Institute (P60-HL15157), by a General Clinical Research Center grant to Children's Hospital (M01 RR 02172) National Institutes of Health and by an FDA Orphan Products Development grant (FDR-001022-01). S. Alper is an Established Investigator of the American Heart Association.

\section{References}

1. Hebbel, R.P. 1991. Beyond hemoglobin polymerization: the red blood cell membrane and sickle disease pathophysiology. Blood. 77:214-237.

2. Eaton, W.A., and J. Hofrichter. 1987. Hemoglobin S gelation and sickle cell disease. Blood. 70:1245-1266.

3. Platt, O.S., S.H. Orkin, G. Dover, G.P. Beardsley, B. Miller, and D.G. Nathan. 1984. Hydroxyurea enhances fetal hemoglobin production in sickle cell anemia. J. Clin. Invest. 74:652-656.

4. Goldberg, M.A., C. Brugnara, G.J. Dover, L. Shapira, S. Charache, and H.F. Bunn. 1990. Treatment of sickle cell anemia with hydroxyurea and erythropoietin. N. Engl. J. Med. 323:366-372.

5. Rodgers, G.P., G.J. Dover, N. Uyesaka, C.T. Noguchi, A.N. Schechter, and A.W. Nienhuis. 1993. Augmentation by erythropoietin of the fetal-hemoglobin response to hydroxyurea in sickle cell disease. N. Engl. J. Med. 328:7380 .

6. Charache, S., G.J. Dover, R.D. Moore, S. Eckert, S.K. Ballas, M. Koshy, P.F.A. Milner, E.P. Orringer, G. Phillips, Jr., O.S. Platt, and G.H. Thomas. 1992. Hydroxyurea: effects on hemoglobin $\mathrm{F}$ production in patients with sickle cell anemia. Blood. 79:2555-2565.

7. Rosa, R.M., B.E. Bierer, R. Thomas, J.S. Stoff, M. Kruskall, S. Robinson, H.F. Bunn, and F.H. Epstein. 1980. A study of induced hyponatremia in the prevention and treatment of sickle cell crisis. N. Engl. J. Med. 303:1138-1143.

8. Charache, S., and W.G. Walker. 1981. Failure of desmopressin to lower serum sodium or prevent crisis in patients with sickle cell anemia. Blood. 58: 892-896.

9. Brugnara, C., H.F. Bunn, and D.C. Tosteson. 1986. Regulation of erythrocyte cation and water content in sickle cell anemia. Science (Wash. DC). 232: 388-390.

10. Canessa, M., A. Spalvins, and R.L. Nagel. 1986. Volume-dependent and NEM-stimulated $\mathrm{K}^{+} \mathrm{Cl}^{-}$transport is elevated in SS, SC and CC human red cells. FEBS Lett. 200:197-202.

11. Brugnara, C., T. Van Ha, and D.C. Tosteson. 1989. Acid pH induces formation of dense cells in sickle erythrocytes. Blood. 74:487-495.

12. Gardos, G. 1958. The function of calcium in the potassium permeability of human erythrocytes. Biochim. Biophys. Acta. 30:653-654.

13. Glader, B.E., and D.G. Nathan. 1978. Cation permeability alterations during sickling: relationship to cation composition and cellular hydration of irreversibly sickled cells. Blood. 51:983-989.

14. Bookchin, R.M., O.E. Ortiz, and V.L. Lew. 1991. Evidence for a direct reticulocyte origin of dense red cells in sickle cell anemia. J. Clin. Invest. 87: 113-124.

15. Brugnara, C., L. De Franceschi, and S.L. Alper. 1993. $\mathrm{C}^{2+}$-activated K transport of human and rabbit erythrocytes: comparison of binding and transport inhibition by scorpion toxins. J. Biol. Chem. 268:8760-8768.

16. Berkowitz, L.R., and P. Orringer. 1981. Effect of cetiedil, an in vitro anti-sickling agent, on erythrocyte membrane cation permeability. J. Clin. Invest. $68: 1215-1220$.

17. Benjamin, L.J., L.R. Berkowitz, E.P. Orringer, V.N. Mankad, A.S. Prasad, L.M. Lewkow, R.K. Chillar, and C.M. Peterson. 1986. A collaborative, double-blind randomized study of cetiedil citrate in sickle cell crises. Blood. 67: 1442-1447.

18. Alvarez, J., M. Montero, and J. Garcia-Sancho. 1992. High affinity inhibition of $\mathrm{Ca}^{2+}$-dependent $\mathrm{K}^{+}$channels by cytochrome P-450 inhibitors. J. Biol. Chem. 267:11789-11793.

19. Brugnara, C., L. De Franceschi, and S.L. Alper. 1993. Inhibition of $\mathrm{Ca}^{2+}$-dependent $\mathrm{K}^{+}$transport and cell dehydration in sickle erythrocytes by clotrimazole and other imidazole derivatives. J. Clin. Invest. 92:520-526.

20. Rittenhouse, A., C. Brugnara, and S.L. Alper. 1994. The antifungal clotrimazole blocks K ${ }^{+}$current in several cell types. J. Gen. Physiol. 104:15a-16a.

21. De Franceschi, L., N. Saadane, M. Trudel, S.L. Alper, C. Brugnara, and Y. Beuzard. 1994. Treatment with oral clotrimazole blocks $\mathrm{Ca}^{2+}$-activated $\mathrm{K}^{+}$ transport and reverses erythrocyte dehydration in transgenic SAD mice. A model for therapy of sickle cell disease. J. Clin. Invest. 93:1670-1676.

22. Brugnara, C., C.A. Armsby, M. Sakamoto, N. Rifai, S.L. Alper, and O. Platt. 1995. Oral administration of clotrimazole and blockade of human erythrocyte $\mathrm{Ca}^{2+}$-activated $\mathrm{K}^{+}$channel: the imidazole ring is not required for inhibitory activity. J. Pharmacol. Exp. Ther. 273:266-272.

23. Lew, V.L., C.J. Freeman, O.E. Ortiz, and R.M. Bookchin. 1991. A mathematical model of the volume, $\mathrm{pH}$ and ion content regulation in reticulocytes. J. Clin. Invest. 87:100-112.

24. Rifai, N., M. Sakamoto, T. Law, O. Platt, M. Mikati, C.C. Armsby, and C. Brugnara. 1995. Measurement by HPLC, blood distribution and pharmacokinetics of oral clotrimazole, a new potential antisickling agent. Clin. Chem. 41: 387-391.

25. Brugnara, C., M.J. Hipp, P.J. Irving, H. Lathrop, P.A. Lee, E.M. Minchello, and J. Winkelman. 1994. Automated reticulocyte counting and measure- 
ment of reticulocyte cellular indices: evaluation of the Miles $\mathrm{H}^{* 3}$ blood analyzer. Am. J. Clin. Pathol. 102:623-632.

26. Seo, M., H. Iida, and Y. Miura. 1977. Basic experiments with clotrimazole administered orally. Curr. Med. Res. Opin. 5:169-178.

27. Weuta, H. 1974. Clinical studies with oral clotrimazole. Postgrad. Med. J. 50(Suppl. 1):45-49.

28. Duhm, B., W. Maul, H. Medenwald, K. Patzschke, J. Puetter, and L.A. Wegner. 1974. The pharmacokinetics of clotrimazole 14C. Postgrad. Med. J. 50(Suppl. 1):13-16.

29. Sawyer, P.R., R.N. Brogden, R.M. Pinder, T.M. Speight, and G.S. Avery. 1975. Clotrimazole: a review of its antifungal activity and therapeutic efficacy. Drugs. 9:424-447.

30. Matsuura, Y., E. Kotani, T. Iio, T. Fukuda, S. Tobinaga, T. Yoshida, and Y. Kuroiwa. 1991. Structure-activity relationship in the induction of hepatic microsomal cytochrome $\mathrm{P} 450$ by clotrimazole and its structurally related compounds in rats. Biochem. Pharmacol. 41:1949-1956.

31. Ortiz, O.E., V.L. Lew, and R.M. Bookchin. 1990. Deoxygenation permeabilizes sickle cell anaemia red cells to magnesium and reverses its gradient in the dense cells. J. Physiol. 427:211-226.

32. Danon, D., and Y. Marikovsky. 1964. Determination of density distribution of red cell population. J. Lab. Clin. Med. 64:668-674.

33. Fabry, M., J.R. Romero, I.D. Buchanan, S.M. Suzuka, G. Stamatoyannopoulos, R.L. Nagel, and M. Canessa. 1991. Rapid increase in red blood cell density driven by the $\mathrm{K}-\mathrm{Cl}$ cotransport in a subset of sickle cell anemia reticulo- cytes and discocytes. Blood. 78:217-225.

34. Franco, R.S., M. Palascak, H. Thompson, and C.H. Joiner. $1995 . \mathrm{KCl}$ cotransport activity in light versus dense transferrin receptor-positive sickle erythrocytes. J. Clin. Invest. 95:2573-2580.

35. Villalobos, C., R. Fonteriz, M. Lopez, A.G. Garcia, and J. Garcia-Sancho. 1992. Inhibition of voltage-gated $\mathrm{Ca}^{++}$entry into $\mathrm{GH} 3$ and chromaffin cells by imidazole antimycotics and other cytochrome P450 blockers. FASEB (Fed. Am. Soc. Exp. Biol.) J. 6:2742-2747.

36. Rhoda, M.D., M. Apovo, Y. Beuzard, and F. Giraud. 1990. $\mathrm{Ca}^{2+}$ permeability in deoxygenated sickle cells. Blood. 75:2453-2458.

37. Benzaquen, L., C. Brugnara, H.R. Byers, S. Gattoni-Celli, and J.A. Halperin. 1995. Clotrimazole inhibits cell proliferation in vitro and in vivo. Nature Med. 1:534-540.

38. Tranquille, N., and J.J. Emeis. 1992. The involvement of products of the phospholipase pathway in the acute release of tissue-type plasminogen activator from perfused rat hindlegs. Eur. J. Pharmacol. 213:285-292.

39. Wick, T.M., J.L. Moake, M.M. Udden, S.G. Eskin, D.A. Sears, and L.V. McIntire. 1987. Unusually large von Willebrand factor multimers increase adhesion of sickle erythrocytes to human endothelial cells under controlled flow. J. Clin. Invest. 80:905-910.

40. De Franceschi, L., P. Rouyer-Fessard, S.L. Alper, H. Jouault, C. Brugnara, and Y. Beuzard. 1996. Combination therapy of erythropoietin, hydroxyurea, and clotrimazole in a $\beta$ thalassemic mouse: a model for human therapy. Blood. 87:1188-1195. 